\title{
The Observations of Latitude Changes Measured in Prague
}

\author{
Zdislav Síma \\ Astronomical Institute of $A V \check{C} R$, Boční II 1401, \\ 14131 Praha 4, Czech Republic; E-mail: sima@ig.cas.cz
}

\begin{abstract}
Astronomy in Prague has long been associated with Charles University, since its founding in 1348. After a long and complicated history, "The State Observatory" was established in the former Jesuit college of Klementinum. The polar height was measured at this location in the last century, during the periods $1889-1892,1895-1899$ and 1900 - 1904. The observations were made by Gerstner, Laska, Spitaler and others, under the leadership of Prof. Lad. Weinek. The measurements were performed with a transit instrument. The inspection was made in the Archive of Academy of Sciences, where practically all the observations are still preserved.
\end{abstract}

\section{The Building of the Observatory}

As is well known the Jesuit Order was founded by St. Ignatius of Loyola in Spain in the year 1534. In the year 1540 the order was approved by the Pope.

As early as 1556 the first Jesuit monks appeared in Prague. Shortly thereafter they began to build their college, called the 'Klementinum' after St Clement (or also Collegium Maximum), together with the associated school called the 'Jesuit Academy.'

The University of Prague - called Charles University - was founded by the emperor Charles IV ${ }^{1}$ on 7 th April 1348. The Papal Privilegium (or Bull) had been issued by Pope Clement VI on 26th January 1347. The University became Utraquist during and after the Hussite revolution $(1419$ - 1434).

This characteristic was retained until the Thirty Years War (1618-1648). Nevertheless, in the year 1622 the two schools merged together. The Jesuits took over the Utraquist University. The Utraquist (Protestant) professors were consequently dismissed - except for the few who converted to Catholicism. The new professors were appointed only from among the members of the Jesuit Order. The Jesuits focused their interest on the philosophical and theological faculty. The history of the natural sciences as taught at the University of Prague is described by Q. Vetter (1952): they were taught only as supplementary subjects.

1 born 14th May 1316 in Prague; died 29th November 1378 in Prague 
The building of the Astronomical Tower of Klementinum College was finished in the year 1722. However, the first director of the "Astronomical Tower," Josef Stepling ${ }^{2}$, was not appointed until the year 1751.

The continuous construction of the college buildings was ended by the abolition of the Jesuit Order on 21st July 1773. The institution of the "Astronomical Tower" was changed into the "State Observatory." Since the time of the abolition of the Order, the Klementinum was not changed much, and remains the second largest complex of buildings in Prague - Prague Castle being the first. The re-establishment of the Jesuit order on 7 th September 1814 did not change the status of the Observatory.

In the year 1954 "State Observatory" was transformed into Astronomical Institute of the Czechoslovak Academy of Sciences, and remains active to this day. Its headquarters are now at Ondřejov.

The history of the Astronomical Tower and of the Museum of Klementinum was described also by Síma (1992).

\section{Measurements of the Polar Height}

\subsection{Director}

The director of the Observatory for the whole period covering all the polar height measurements in Prague was Ladislaus (original Lászlo) Weinek. His brief Curriculum Vitae is as follows:

Born on 13th Febr. 1848 in Buda (Ofen), Hungary,

In $1865-1873$ he studied in Wien,

In 1875 - 1883 he was an observer at the Observatory in Leipzig, Germany,

He received Doctorate (title doctor) 1879 in Jena University,

In the year 1883 he came to Prague (German) University,

In the years 1883 - 1913 he was a director of the State Observatory in Prague,

He pursued diligently measurements of the polar height in the years $1889-$ 1892 and $1895-1899$,

In the year 1893 he received a title Doctor Honoris Causa in Berkeley (USA),

In the years 1897 - 1900 he made a Photographic Atlas of the Moon (about 200 pages),

During the years $1900-1904$, the observations of the polar height were continued.

He died 12th November 1913 in Prague, Bohemia. More details are in Scheller (1913).

\subsection{The Instrument and Observers}

- Transit Instrument Pistor \& Martins, entrance aperture $68 \mathrm{~mm}$, Focal Length $870 \mathrm{~mm}$

2 born 26 th (or 29 th or 30 th) June 1716 in Regensburg (Germ.); died 11th July 1778 in Prague 
- Observers: Dr. Gustav Gruss, Dr. Rudolf Spitaler, Dr. Robert Lieblein, Dr. Egon Ritter von Oppolzer, Dr. Artur Scheller, Berann, Prof. L. Weinek

- Method: Horrebow - Talcott (1732 Peter Horrebow theory and 1851 Andrew Talcott practice)

- Observatory: Not preserved; however, it was only several meters from the Astronomical Tower. It is possible to determine the position of the instrument by GPS. (See Figs. 1 - general view and Fig. 2-detail of the roof of an observing hut for transit instruments).

\subsection{The Measurements}

- Observational record books (work-books) are still kept in the Archive of the Academy of Sciences, Prague. (e.g.: Signature III A 1). I personally went through this extensive material.

- A lot of tables, plans, and calculations are still preserved in the Archive. They are also well-preserved.

- The measurements can, in principle, be reduced again today. They can therefore be used to extend the data set that is commonly used to determine the polar movement (from 1900 - today; e.g. Gross \& Vondrák 1999). This extension would allow for the data set to start in 1889 .

- The results of reductions were published by Weinek in: "Definitive Resultate aus den Prager ...", Haase, Prag, 1903 (293 pages). It is highly probable that the old (reduced) measurements taken from the book of Weinek (1903) even without a new reduction of the original observations can be useful for the period about ten years as mentioned above.

- The results of the Prague polar height measurements are not unknown (e.g. Rambousek 1974), however, they are used only very rarely, e.g. Fedorov, Korsuñ, Major, Pančenko, Taradij, Jackiv: "Dviženie poljusa Zemli s 1890.0 po 1969.0 ", Naukova Dumka, Kiev, 1972, or Höpfner (1999).

- The results from the second series of observations were published by A. Scheller: Polhöhenmessungen nach der Horrebow - Talcott'schen Methode von 1900 bis $1904 \ldots$, in Astronomische Beobachtungen an der $K$. $K$. Sternwarte zu Prag, ed. L. Weinek, Haase, Prag, 1907, pp. $15-44$.

- This second series is nearly forgotten today.

- The question arises: Is it worthwhile to reduce all the measurements again in order to cover the longer period of the pole observation? This would require considerable work.

Acknowledgments. The author wants to express his thanks to the organizers of this conference enabling him to come to Cagliari, to the workers of the Archive of the Academy of Sciences, Prague, Bohnice, and to Ing. Jan Rambousek. 


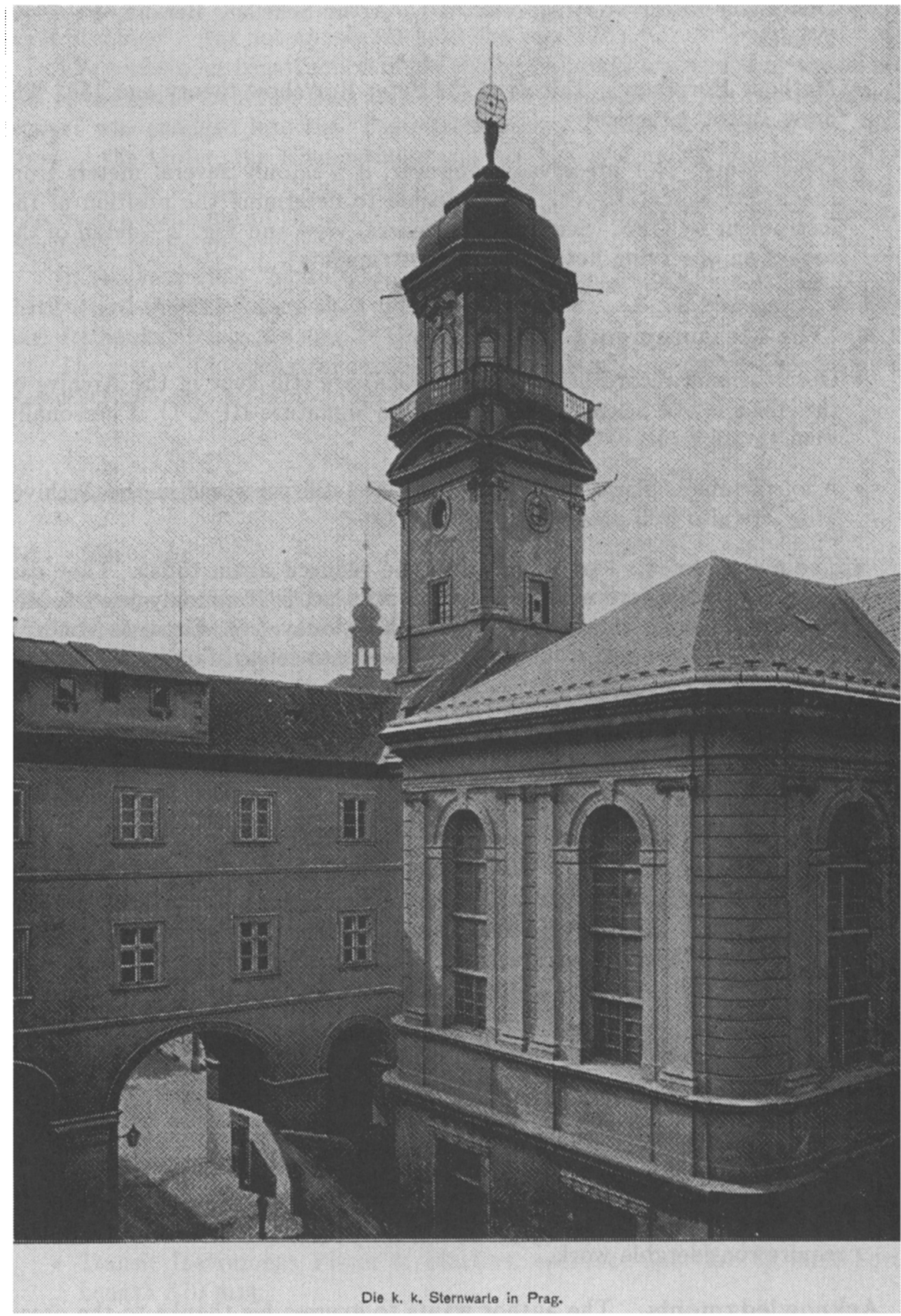

Figure 1. General view of an observing hut. 


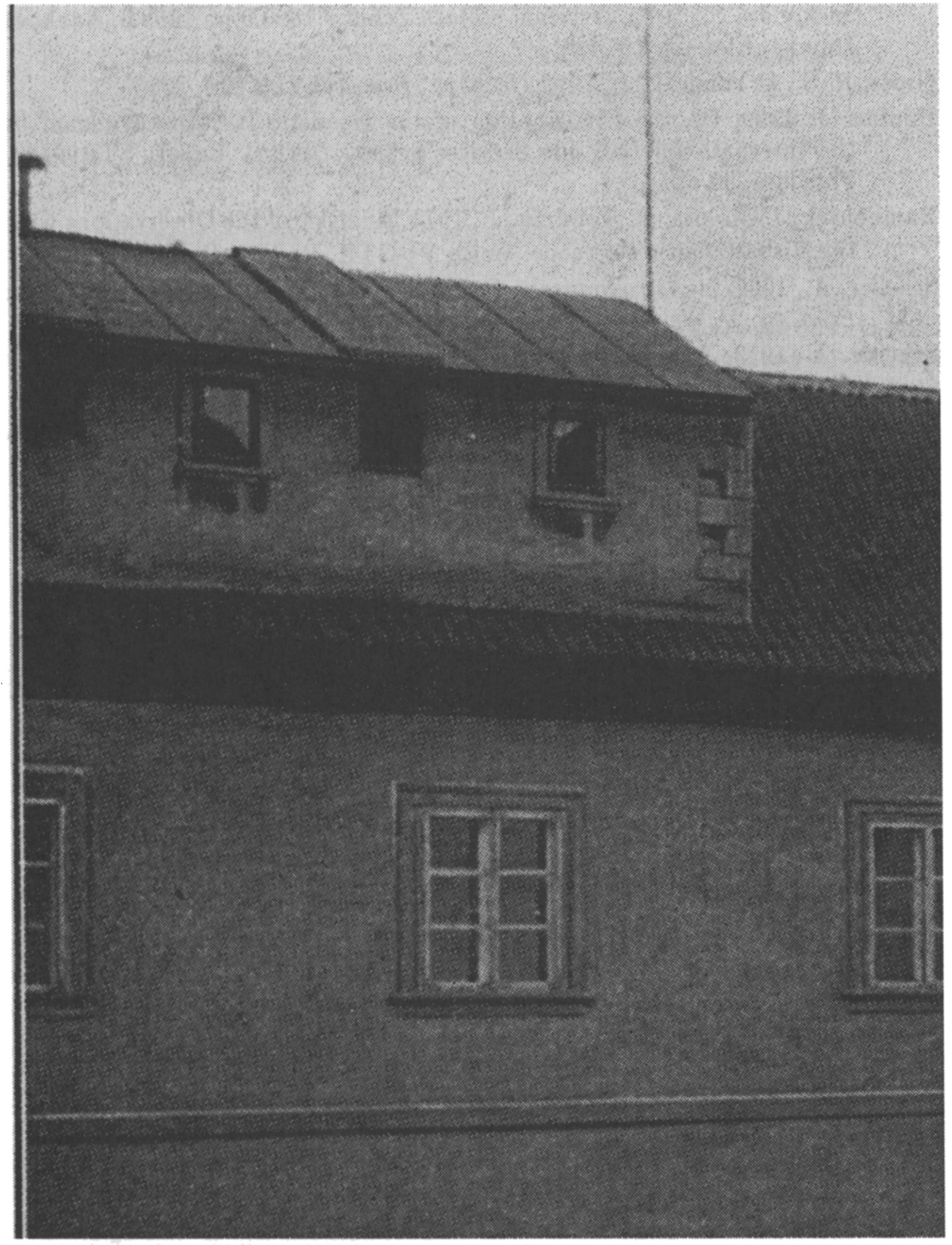

Figure 2. Detail of the roof of an observing hut. 


\section{References}

Fedorov, E. P., Korsuñ, A. A., Major, S. P. Pančenko, N. I., Taradij, V. K., Jackiv Ja. S., 1972, Dviženie poljusa Zemli s 1890.0 po 1969.0 , Naukova Dumka, Kiev [in Russian].

Gross, R. S., \& Vondrák, J., 1999 Geophys. Research Lett. 26, 2085.

Höpfner J. 1999, On the Contribution of the Geodetic Institute Potsdam to the International Latitude Service, Scient. Techn. Report STR99/09, Potsdam, $30 \mathrm{pp}$.

Rambousek, J., Holota, P., Vondrák, J., 1974, Analysis of the Observations with the Visual Zenith-Telescope, Edice VÚGTK, Řada 4, Praha.

Scheller, A., 1907, in Astronomische Beobachtungen an der K. K. Sternwarte zu Prag, ed. L. Weinek, Haase, Prag, 1907, 15 [in German].

Scheller, A., 1913, Astron. Nachrich. 196, 323.

Síma, Z. 1992, Bull. of the Scientific Instrument Soc., No.35, December, 7.

Vetter, Q., 1952, Šest století ..., in Vèstník král. české spol. nauk, třída matematicko-prírodov. No. XIV, 1-40 pp. [in Czech]. 